\title{
Pancuronium Does Not Alter the Hemodynamic Status of Piglets after Normoxia or Hypoxia ${ }^{1}$
}

\author{
DAVID EASA, CATHERINE F. T. UYEHARA, EDWARD L. STEVENS, KUULEIALOHA C. FINN, \\ VENKATARAMAN BALARAMAN, AND HELEN SIM \\ Department of Pediatrics [D.E., V.B., K.C.F., H.S.]. Kapiolani Medical Center for Women and Children, John A. \\ Burns School of Medicine, Honolulu, Hawaii 96826, and Departments of Clinical Investigation [C.F.T.U.] and \\ Pediatrics [E.L.S.], Tripler Army Medical Center. Hawaii 96859
}

\begin{abstract}
Pancuronium is a neuromuscular blocking agent commonly used to eliminate agitation in sick newborn infants requiring mechanical ventilation. Experimental data supporting this method of intervention are controversial, and hemodynamic studies in newborn infants report conflicting results. This study was designed to determine the hemodynamic effects of pancuronium administered under conditions of normoxia, hypoxia, and preexposure to hypoxia in neonatal piglets with normal lungs. After baseline hemodynamic and blood gas measurements were obtained, pancuronium was administered in two i.v. bolus injections of $0.1 \mathrm{mg} / \mathrm{kg}$. Tidal volume and minute ventilation were maintained constant during the experimental procedure by adjusting ventilator settings. Twenty min after pancuronium, no changes from baseline values were found in arterial blood gases, heart rate, cardiac output, mean arterial pressure, systemic vascular resistance, pulmonary artery pressure, pulmonary vascular resistance, central venous pressure, or pulmonary capillary wedge pressure in any of the three conditions studied. In conclusion, pancuronium administered during normoxia, hypoxia, or after preexposure to hypoxia while controlled ventilation is maintained does not alter systemic or pulmonary hemodynamic status of the newborn piglet. (Pediatr Res 33: 365-372, 1993)
\end{abstract}

\section{Abbreviations}

CO, cardiac output

CVP, central venous pressure

$\mathrm{FiO}_{2}$, fraction of inspired oxygen

HR, heart rate

MAP, mean arterial pressure

PAP, pulmonary artery pressure

PCWP, pulmonary capillary wedge pressure

PIP, peak inspiratory pressure

$\mathrm{PaO}_{2}$, partial pressure arterial $\mathrm{O}_{2}$

$\mathrm{PaCO}_{2}$, partial pressure arterial $\mathrm{CO}_{2}$

PVR, pulmonary vascular resistance

SVR, systemic vascular resistance

$V_{T}$, tidal volume

$V_{\mathrm{E}}$, minute ventilation
Pancuronium is the most common neuromuscular blocking agent used in the neonatal intensive care unit (1). It is used to treat sick newborn infants requiring mechanical ventilation in an effort to eliminate agitation and permit synchronous breathing with the ventilator (2). When pancuronium is used for this purpose, some studies document improved oxygenation $(3,4)$, whereas others report the opposite $(5,6)$.

Studies of the hemodynamic effects of pancuronium administration in newborn infants are also equivocal. A spectrum of effects has been reported including increasing (7) or decreasing blood pressure (8), increasing HR (7), and no effect on HR or blood pressure $(4,9-11)$. Because pancuronium is currently used for treating sick infants without a consensus regarding its effects on oxygenation and hemodynamic function, its therapeutic use has remained controversial $(1,2)$.

Different responses to pancuronium may reflect differences in the pulmonary hemodynamic status of the newborn infant before pancuronium administration. For example, pancuronium (as well as other pharmacologic agents) may exhibit different effects depending on whether it is given during baseline normoxic conditions or when the pulmonary vasculature is sensitized to vasoconstrictive stimuli during, or even after, preexposure to hypoxia (12-14). Alternatively, if the pulmonary vasculature is already maximally vasoconstricted during hypoxia, no further vasoconstrictive action by pancuronium may be detected. In any case, the use of pancuronium in the hypoxic, sick newborn infant at risk for pulmonary hypertension may have dramatically different effects from those observed in an infant with normal pulmonary function.

Also, it is possible that rather than being direct effects of the drug, the reported hemodynamic effects of pancuronium may represent a secondary response to altered ventilation. Druginduced muscle paralysis of infants who during mechanical ventilation are breathing spontaneously may lead to hypoventilation after the loss of spontaneous respirations $(15,16)$. This could stimulate the release of catecholamines, resulting in elevation of HR and blood pressure (7). Maintaining adequate ventilation by increasing PIP immediately before pancuronium administration has been shown to decrease noradrenaline levels and prevent blood pressure changes in infants (17). In other circumstances, spontaneous respirations may interfere with otherwise adequate mechanical ventilation, and pancuronium administration may improve ventilation while preventing catecholamine-mediated hemodynamic effects. This concept is supported by Crone and Favorito (4), who demonstrated improvement in $\mathrm{PaO}_{2}$ and reduction in $\mathrm{PaCO}_{2}$ without changes in HR or blood pressure after pancuronium administration.

Therefore, in this study we investigated whether different conditions of normoxia, hypoxia, or preexposure to hypoxia could be responsible for variable hemodynamic and blood gas responses to pancuronium. We hypothesized that under these conditions, pancuronium would not result in perturbations in
Recespondence: David Easa M.D. Kapiolani Medical Center for Women and Children, 1319 Punahou St., Honolulu, HI 96826.

Supported by the U.S. Health Service Command (C.F.T.U., E.L.S.) and Kapiolani Medical Center for Women and Children (D.E., K.C.F., V.B., H.S.). The NVM-1 neonatal volume monitor was provided by the Bear Medical System Corporation, Riverside, CA.

The opinions or assertions contained herein are the private views of the authors and are not to be construed as official or as reflecting the views of the Department of the Army or the Department of Defense. 


\section{Stabilization Normoxia $\square$ Hypoxia}

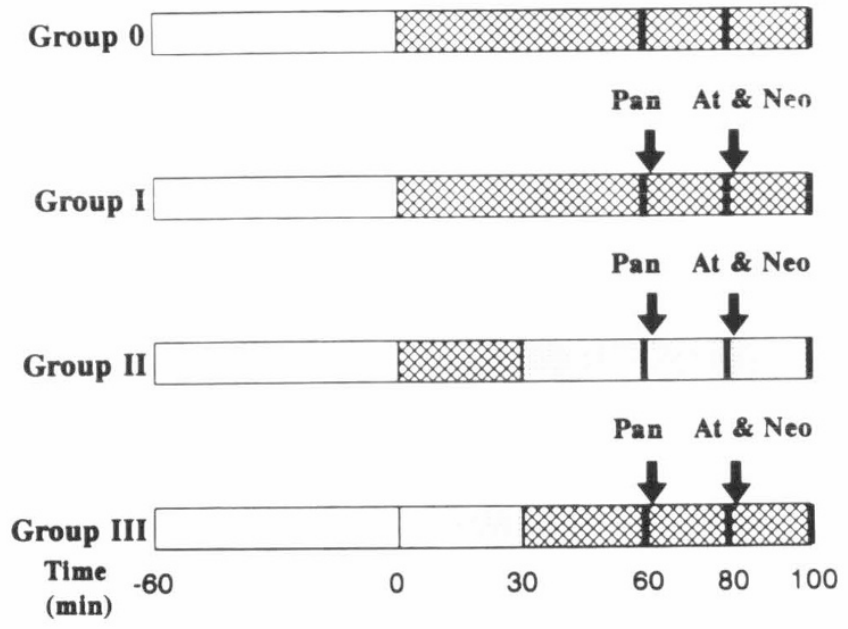

Fig. 1. Outline of study design with groups designated as 0 , I, II, and III. Arrows are time points when drugs were administered. Pan, pancuronium; At \& Neo, atropine and neostigmine. The black vertical bars at 60. 80, and 100 min represent measurement times; results are shown in Figures 2-6. The measurement at $60 \mathrm{~min}$ represents a baseline just before pancuronium administration (designated Baseline in Figs. 2-6). The 80min measurement represents effects $20 \mathrm{~min}$ after pancuronium (designated Pan in Figs. 2-6). The 100-min measurement represents effects 20 min after atropine and neostigmine (designated At \& Neo in Figs. 2-6). hemodynamic function if $\mathrm{V}_{\mathrm{T}}$ and $\mathrm{V}_{\mathrm{E}}$ were maintained constant after drug administration.

\section{MATERIALS AND METHODS}

Animal preparation. This study was approved by the Institutional Animal Use and Care Committee of Tripler Army Medical Center and was in compliance with the Animal Welfare Act. Twenty-three newborn pigs of either sex, $6.5 \pm 1 \mathrm{~d}$ postnatal age. weighing $2.2 \pm 0.2 \mathrm{~kg}$ (Shimokawa Farms, Waimanalo, HI) were studied in the supine position after intraperitoneal anesthesia with pentobarbital sodium $30 \mathrm{mg} / \mathrm{kg}$ (Wyeth Laboratories, Philadelphia, PA) supplemented by $5-10 \mathrm{mg} / \mathrm{kg}$ intraarterially as needed. Piglets were intubated with a $3.0-\mathrm{mm}$ cuffed endotracheal tube for mechanical ventilation with a Baby Bird pediatric ventilator (Bird Corp., Palm Springs, CA).

Initial ventilator settings were PIP $1.18-1.37 \mathrm{kPa}(12-14 \mathrm{~cm}$ $\left.\mathrm{H}_{2} \mathrm{O}\right)$, positive end-expiratory pressure $0.20 \mathrm{kPa}\left(2 \mathrm{~cm} \mathrm{H}_{2} \mathrm{O}\right)$, rate $35-40 / \mathrm{min}$, inspiratory time $0.35 \mathrm{~s}$, and $\mathrm{FiO}_{2} 0.21$. Blood gas values were maintained at $\mathrm{pH} 7.35-7.45, \mathrm{PaCO}_{2} 4.67-6.00$ $\mathrm{kPa}$ (35-45 torr), and $\mathrm{PaO}_{2} 8.00-10.67 \mathrm{kPa}$ (60-80 torr) by appropriate ventilator adjustments. Ventilator parameters were set and monitored with a microprocessor-based ventilator monitor (model 1200, Novametrics, Wallingford, CT), on-line $\mathrm{CO}_{2}$ was monitored with an end-tidal $\mathrm{CO}_{2}$ monitor (model 47210A, Hewlett-Packard Co., Palo Alto, CA), and $\mathrm{V}_{\mathrm{T}}$ (inspiratory and expiratory) and $\mathrm{V}_{\mathrm{E}}$ were monitored with a neonatal $\mathrm{V}_{\mathrm{T}}$ monitor (Bear Medical Systems NVM-1, Riverside, CA). The validity of this monitor, using a hot-wire anemometer to measure $\mathrm{V}_{\mathrm{T}}$, has recently been demonstrated $(18,19)$.

The femoral artery was cannulated with a 4 French doublelumen catheter (Cook Inc., Bloomington, IN) for arterial blood sampling and measuring MAP. The femoral vein was cannulated with a $0.06-\mathrm{mm}$ outer diameter catheter (Norton Performance Plastics, Akron, $\mathrm{OH}$ ) for continuous infusion of normal saline, $100 \mu \mathrm{L} / \mathrm{kg} / \mathrm{min}$. The right external jugular was cannulated with a 5 French Swan-Ganz catheter (Baxter Healthcare Corp., Irvine,

Table 1. Ventilatory parameters and hemodynamic values for group 0 vs group $I^{*}$

\begin{tabular}{|c|c|c|c|c|c|c|}
\hline & \multicolumn{3}{|c|}{ Group $0(n=5)$} & \multicolumn{3}{|c|}{ Group I $(n=6)$} \\
\hline & $60 \mathrm{~min}$ & $80 \mathrm{~min}$ & $100 \mathrm{~min}$ & $\begin{array}{c}60 \mathrm{~min} \\
\text { (baseline) }\end{array}$ & $80 \min (\operatorname{Pan})$ & $\begin{array}{c}100 \mathrm{~min} \\
(\text { At \& Neo) }\end{array}$ \\
\hline $\mathrm{V}_{\mathrm{T}}(\mathrm{mL} / \mathrm{kg})$ & $9.3 \pm 0.5$ & $9.2 \pm 0.5$ & $9.1 \pm 0.5$ & $10.6 \pm 1.0$ & $10.9 \pm 1.0$ & $10.5 \pm 0.9$ \\
\hline $\mathrm{V}_{\mathrm{E}}(\mathrm{L} / \mathrm{min})$ & $0.87 \pm 0.1$ & $0.86 \pm 0.1$ & $0.85 \pm 0.1$ & $1.02 \pm 0.25$ & $1.03 \pm 0.25$ & $0.99 \pm 0.23$ \\
\hline $\mathrm{pH}$ & $7.46 \pm 0.01$ & $7.46 \pm 0.01$ & $7.46 \pm 0.01$ & $7.43 \pm 0.01$ & $7.42 \pm 0.012$ & $7.41 \pm 0.009$ \\
\hline $\mathrm{PaCO}_{2}(\mathrm{kPa})$ & $5.12 \pm 0.11$ & $5.15 \pm 0.11$ & $5.17 \pm 0.09$ & $5.23 \pm 0.08$ & $5.19 \pm 0.15$ & $5.41 \pm 0.15$ \\
\hline $\mathrm{PaCO}_{2}$ (torr) & $38.4 \pm 0.8$ & $38.64 \pm 0.8$ & $38.8 \pm 0.7$ & $39.2 \pm 0.6$ & $38.9 \pm 1.1$ & $40.6 \pm 1.1$ \\
\hline $\mathrm{PaO}_{2}(\mathrm{kPa})$ & $9.62 \pm 0.12$ & $9.53 \pm 0.15$ & $9.52 \pm 0.12$ & $10.2 \pm 0.39$ & $10.21 \pm 0.43$ & $9.70 \pm 0.27$ \\
\hline $\mathrm{PaO}_{2}$ (torr) & $72.2 \pm 0.9$ & $71.5 \pm 1.1$ & $71.4 \pm 0.9$ & $76.5 \pm 2.9$ & $76.6 \pm 3.2$ & $72.8 \pm 2.0$ \\
\hline \multicolumn{7}{|l|}{ Systemic } \\
\hline HR (beats/min) & $201 \pm 8$ & $207 \pm 10$ & $204 \pm 13 \dagger$ & $226 \pm 12$ & $235 \pm 11$ & $245 \pm 8$ \\
\hline $\mathrm{CO}(\mathrm{mL} / \mathrm{min} / \mathrm{kg})$ & $225 \pm 26$ & $225 \pm 23$ & $241 \pm 23$ & $209 \pm 12$ & $209 \pm 9$ & $218 \pm 25$ \\
\hline $\mathrm{MAP}(\mathrm{kPa})$ & $10 \pm 0.4 \dagger$ & $10 \pm 0.4 \dagger$ & $9.6 \pm 0.4$ & $8.13 \pm 0.53$ & $8.13 \pm 0.4$ & $8.4 \pm 0.4$ \\
\hline $\mathrm{MAP}(\mathrm{mm} \mathrm{Hg})$ & $75 \pm 3 \dagger$ & $75 \pm 3 \dagger$ & $72 \pm 3$ & $61 \pm 4$ & $61 \pm 3$ & $63 \pm 3$ \\
\hline $\mathrm{SVR} \mathrm{kPa} /(\mathrm{mL} / \mathrm{min} / \mathrm{kg})$ & $0.04 \pm 0.005$ & $0.04 \pm 0.004$ & $0.04 \pm 0.005$ & $0.04 \pm 0.004$ & $0.04 \pm 0.003$ & $0.04 \pm 0.004$ \\
\hline $\mathrm{SVR} \mathrm{mm} \mathrm{Hg} /(\mathrm{mL} / \mathrm{min} / \mathrm{kg})$ & $0.35 \pm 0.04$ & $0.34 \pm 0.03$ & $0.33 \pm 0.04$ & $0.29 \pm 0.03$ & $0.29 \pm 0.02$ & $0.29 \pm 0.03$ \\
\hline \multicolumn{7}{|l|}{ Pulmonary } \\
\hline $\operatorname{PAP}(\mathrm{kPa})$ & $1.87 \pm 0.13$ & $1.87 \pm 0.13$ & $1.87 \pm 0.13$ & $2.4 \pm 0.13$ & $2.4 \pm 0.13$ & $2.27 \pm 0.13$ \\
\hline PAP $(\mathrm{mm} \mathrm{Hg})$ & $14 \pm 1$ & $14 \pm 1$ & $14 \pm 1$ & $18 \pm 1$ & $18 \pm 1$ & $17 \pm 1$ \\
\hline PVR kPa (mL/min/kg) & $0.007 \pm 0.001$ & $0.006 \pm 0.001$ & $0.006 \pm 0.001$ & $0.008 \pm 0.001$ & $0.008 \pm 0$ & $0.007 \pm 0$ \\
\hline PVR mmHg $(\mathrm{mL} / \mathrm{min} / \mathrm{kg})$ & $0.05 \pm 0.01$ & $0.05 \pm 0.01$ & $0.05 \pm 0.01$ & $0.06 \pm 0.01$ & $0.06 \pm 0$ & $0.06 \pm 0$ \\
\hline $\mathrm{CVP}(\mathrm{kPa})$ & $0.21 \pm 0.02$ & $0.19 \pm 0.02$ & $0.19 \pm 0.02$ & $0.24 \pm 0.02$ & $0.27 \pm 0.02$ & $0.27 \pm 0.02$ \\
\hline CVP (mm Hg) & $1.6 \pm 0.14$ & $1.4 \pm 0.14$ & $1.4 \pm 0.14$ & $1.8 \pm 0.13$ & $2 \pm 0.13$ & $2 \pm 0.13$ \\
\hline $\mathrm{PCWP}(\mathrm{kPa})$ & $0.37 \pm 0.05$ & $0.43 \pm 0.05$ & $0.4 \pm 0.05$ & $0.71 \pm 0.04$ & $0.78 \pm 0.04$ & $0.64 \pm 0.04$ \\
\hline PCWP (mm Hg) & $2.8 \pm 0.35$ & $3.2 \pm 0.35$ & $3 \pm 0.35$ & $5.33 \pm 0.32$ & $5.83 \pm 0.32$ & $4.83 \pm 0.32$ \\
\hline
\end{tabular}

* Values are mean \pm SEM. Pan, after paralysis with pancuronium; At \& Neo, after treatment with atropine and neostigmine.

† Group 0 different from group I; $p<0.05$. 

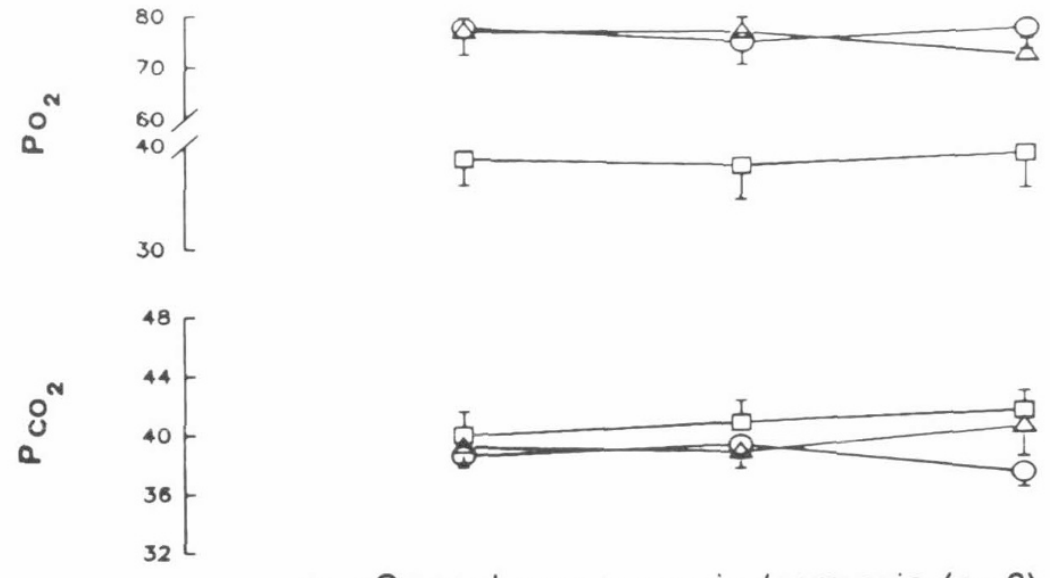

$\Delta$ - Group I, pre-normoxia /normoxia $(n=6)$

口 - Group II, pre-normoxia /hypoxia $(n=6)$

o - Group III, pre-hypoxia / normoxia $(n=6)$

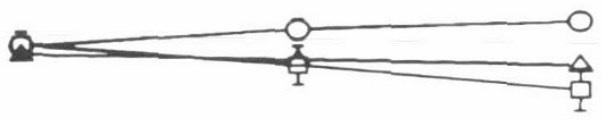

F ${ }^{2}{ }^{12}$

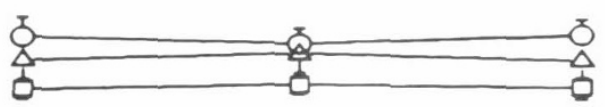

$>\frac{\widehat{c}}{\frac{5}{2}}{ }^{1.6}$

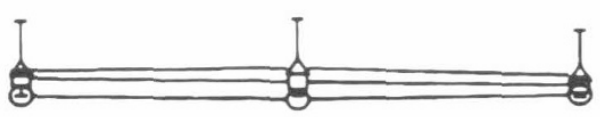

Baseline

Pan

At \& Noo

Fig. 2. $\mathrm{PaO}_{2}, \mathrm{PaCO}_{2}, \mathrm{pH}, \mathrm{V}_{\mathrm{T}}(T V)$, and $\mathrm{V}_{\mathrm{E}}$ in group I vs II vs III. Baseline, before pancuronium; Pan, 20 min after pancuronium; At \& Neo, 20 min after atropine and neostigmine. $\mathrm{PaO}_{2}$ and $\mathrm{PaCO}_{2}$ units are torr: $\mathrm{PaO}_{2}$ or $\mathrm{PaCO}_{2}$ in $\mathrm{kPa}=$ value $\times 0.1333$. Values are mean \pm SEM.

CA), after which the tip was advanced to the pulmonary artery for measurement of PAP, PCWP, and CO. Confirmation of catheter placement was made by identifying the characteristic wave forms and at autopsy. A 4 French polyurethane catheter (Arrow International Inc., Reading, PA) was inserted into the right atrium via the left external jugular vein for measurement of CVP and administration of cold dextrose $(5 \%$ in water) for $\mathrm{CO}$ determination by thermodilution (Hewlett-Packard model $66 \#$ M1176A6). Femoral artery, right atrial, and Swan-Ganz catheters were connected to pressure transducers (Hewlett-Packard model 1290A for CVP, model 1290C for PAP and MAP), zeroed at the midcardiac level, and signals were recorded and displayed with a monitor (Hewlett-Packard model 66\#M1176A6). Body temperature was monitored continuously with a rectal probe connected to the Hewlett-Packard monitor and was maintained between $38^{\circ}$ and $39^{\circ} \mathrm{C}$ by use of a heating pad. Arterial blood was drawn at preset intervals for measurement of blood gases (model $168 \mathrm{pH} /$ blood gas analyzer, Corning Medical, Medfield, MA), osmolality, hematocrit, and electrolytes.
Experimental design. After instrumentation and $60 \mathrm{~min}$ of stabilization, piglets were randomly assigned to one of four groups and studied as outlined in Figure 1. Groups I, II, and III were all treated with pancuronium (Astra Pharmaceutical Products, Westborough, MA; $0.1 \mathrm{mg} / \mathrm{kg}$ i.v., two rapid bolus injections administered $5 \mathrm{~min}$ apart) after baseline values were obtained. Twenty min after pancuronium administration, atropine (Elkins-Sinn Inc., Cherry Hill, NJ; $0.02 \mathrm{mg} / \mathrm{kg}$ i.v.) and neostigmine (Squibb-Marsam, Princeton, NJ; $0.08 \mathrm{mg} / \mathrm{kg}$ i.v.) were given to reverse any pancuronium effects. Another group of piglets was studied as a normoxia control group (group 0) not exposed to pancuronium to verify the stability of the animal preparation and document that there were no hemodynamic changes over time in piglets not exposed to pancuronium.

Group I piglets were subjected to normoxia $\left(\mathrm{FiO}_{2}=0.21\right)$ throughout the experiment. Group II piglets were subjected to $30 \mathrm{~min}$ of normoxia, followed by $70 \mathrm{~min}$ of hypoxia $\left(\mathrm{FiO}_{2}=\right.$ 0.15 ); drugs were administered during hypoxia. Group III piglets 

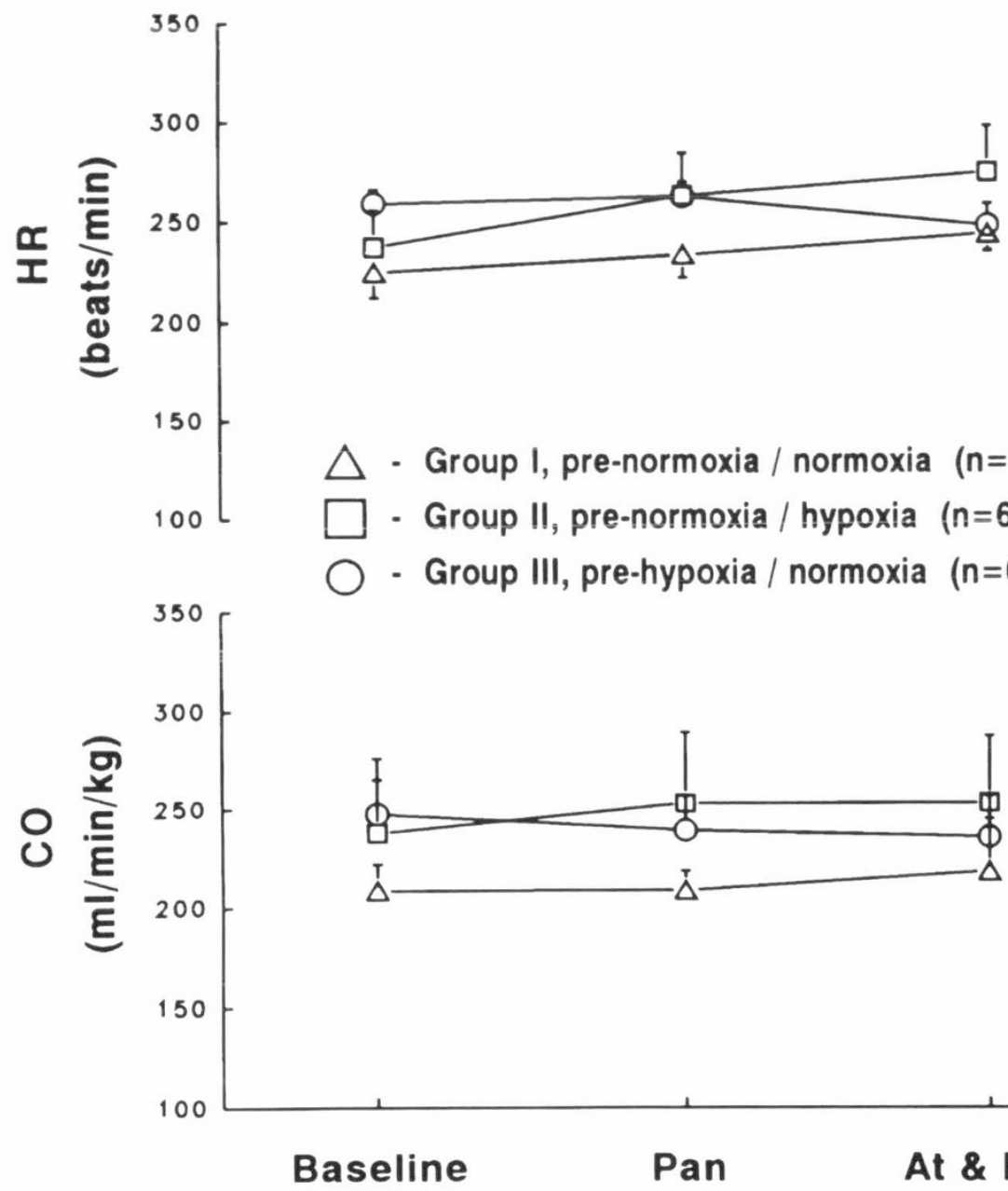

- Group I, pre-normoxia / normoxia $(n=6)$

- Group II, pre-normoxia / hypoxia $(n=6)$

- Group III, pre-hypoxia / normoxia $(n=6)$

Baseline

Fig. 3. HR and $\mathrm{CO}$ in group I vs II vs III. Values are mean $\pm \mathrm{SEM}$. were subjected to $30 \mathrm{~min}$ of hypoxia followed by $70 \mathrm{~min}$ of normoxia; drugs were administered during normoxia (Fig. 1). Hypoxia $\left(\mathrm{FiO}_{2}=0.15\right)$ was achieved with a mixture of nitrogen in air.

Hemodynamic measurements (MAP, HR, CO, PAP, PCWP, and CVP) were recorded and blood was sampled just before pancuronium, $20 \mathrm{~min}$ after pancuronium, and $20 \mathrm{~min}$ after reversal of pancuronium action with atropine and neostigmine. Although these values represent spot measurements, hemodynamic and pulmonary function parameters were continuously observed before, during, and after drug administration; the 20min values were representative of the entire preceding 20 -min period. Arterial blood $(0.3 \mathrm{~mL})$ was drawn for measurement of blood gases. An additional blood sample $(1.0 \mathrm{~mL})$ was drawn and plasma was separated for osmolality (micro-osmometer model 3MO, Advanced Instruments, Needham Heights, MA), hematocrit, and sodium and potassium (ASTRA-4, Beckman Instruments, Brea, CA) analyses. The remaining red blood cells were reinfused after reconstitution in normal saline within 10 min of blood sampling.

End-tidal $\mathrm{CO}_{2}, \mathrm{~V}_{\mathrm{T}}$, and $\mathrm{V}_{\mathrm{E}}$ were continuously monitored. When necessary during pancuronium administration, the ventilator was immediately adjusted to maintain a constant $\mathrm{V}_{\mathrm{T}}$ and $\mathrm{V}_{\mathrm{E}}$. PIP was adjusted $\left[-0.29\right.$ to $+0.49 \mathrm{kPa}\left(-3\right.$ to $\left.\left.+5 \mathrm{~cm} \mathrm{H}_{2} \mathrm{O}\right)\right]$ to maintain $\mathrm{V}_{\mathrm{T}}$; rate was adjusted no more than three breaths per min to maintain $\mathrm{V}_{\mathrm{E}}$. The importance of immediate ventilatory changes to avoid decreases in $V_{T}$ and $V_{E}$ was demonstrated in two preliminary experiments. When $V_{T}$ and $V_{E}$ were not controlled, pancuronium administration resulted in an immediate elevation in PAP (increasing $35 \%$ and $100 \%$, respectively) associated with a decrease in $\mathrm{V}_{\mathrm{E}}$, presumably as a result of respiratory acidosis and/or hypercarbia (20). PVR and SVR were calculated by standard formulas as follows:

$$
\begin{aligned}
\mathrm{PVR} & =(\mathrm{PAP}-\mathrm{PCWP}) /(\mathrm{CO} / \mathrm{KG}) \\
\mathrm{SVR} & =(\mathrm{MAP}-\mathrm{CVP}) /(\mathrm{CO} / \mathrm{KG})
\end{aligned}
$$

At the conclusion of each experiment, an autopsy was performed to examine cardiac anatomy, confirm catheter placement, and evaluate the status of the ductus arteriosus.

Data analysis. The results were analyzed by two-way analysis of variance for repeated measures. When significance $(p<0.05)$ was achieved, the Duncan's multiple range posthoc test was used for multiple comparisons between and within groups. All data are expressed as mean \pm SEM.

\section{RESULTS}

Hematocrit, serum sodium, potassium, and osmolality were unchanged at 60,80 , and $100 \mathrm{~min}$ in all study groups, verifying the stability of fluid and electrolyte balance in this animal model.

Effect of pancuronium on stability of systemic and pulmonary hemodynamics during normoxia: group 0 versus group I. Table 1 summarizes the results of group 0 and group I piglets. There were no differences in the measurements over time in the group 0 control group. Also, there were no significant differences when comparing measurements taken at baseline with those after paralysis with pancuronium or after treatment with atropine and neostigmine in group $\mathrm{I}$. 

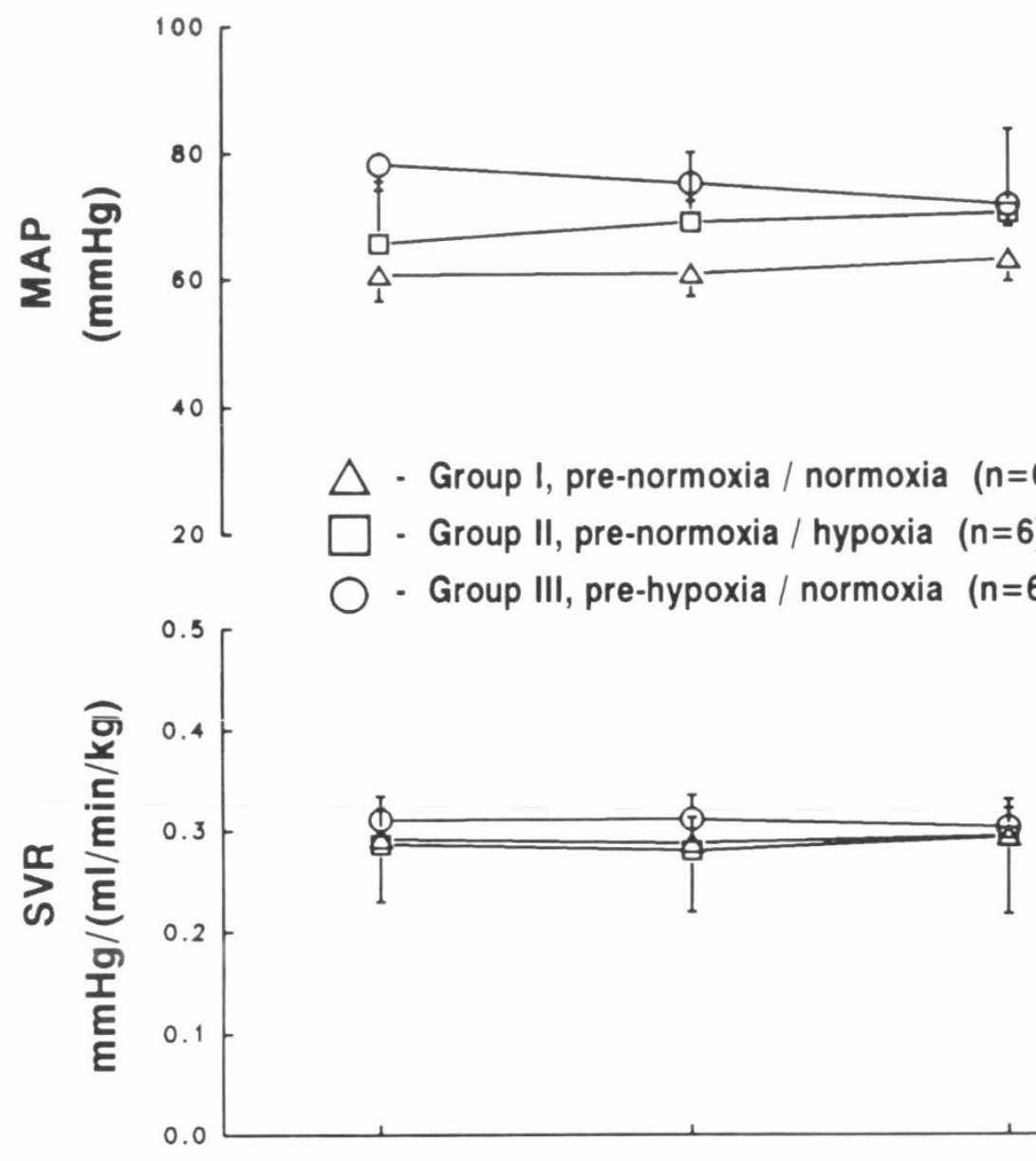

\section{$\triangle$ - Group I, pre-normoxia / normoxia $(n=6)$ \\ - Group II, pre-normoxia / hypoxia $(n=6)$ \\ - Group III, pre-hypoxia / normoxia $(n=6)$}

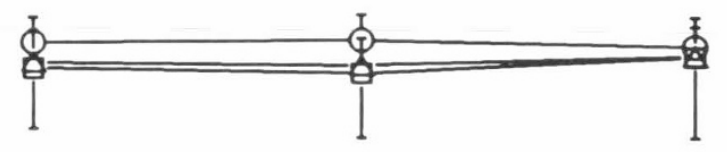

Baseline

Pan

At \& Neo

Fig. 4. MAP and SVR in group I vs II $v$ III. MAP or SVR in $\mathrm{kPa}=$ value $\times 0.1333$. Values are mean $\pm \mathrm{SEM}$.

Effect of hypoxia before or during pancuronium administration on systemic and pulmonary hemodynamics: group I versus group II versus group III. $\mathrm{PaO}_{2}, \mathrm{PaCO}_{2}, \mathrm{pH}, \mathrm{V}_{\mathrm{T}}$, and $\mathrm{V}_{\mathrm{E}}$ remained stable before and after pancuronium administration in all groups (Fig. 2).

There were no differences in starting systemic hemodynamic values between groups I, II, and III. Within each group, HR and CO (Fig. 3), and MAP and SVR (Fig. 4), remained stable with no significant differences before and throughout the 20-min period after pancuronium administration. Similarly, blockade of any pancuronium effects with atropine and neostigmine caused no changes in systemic hemodynamic parameters up to $20 \mathrm{~min}$ after administration.

Reflecting the pulmonary hemodynamic response to hypoxia, starting PAP and PVR values were significantly higher in group II as compared with groups I and III (Fig. 5). Nevertheless, PAP and PVR (Fig. 5), and CVP and PCWP (Fig. 6), remained stable with no significant differences before and throughout the 20 -min period after pancuronium administration in all three groups studied. Blockade of pancuronium action with atropine and neostigmine did not change pulmonary hemodynamic parameters. Thus, hypoxia or preexposure to hypoxia did not alter the apparent lack of effect of pancuronium on hemodynamic function.

At autopsy, although we did not definitively rule out ductal shunting, we were able to find only small probe-patent ductal orifices. This is consistent with the developmental and anatomical descriptions of Haworth and Hislop (21) and Evans et al. (22) for pigs at this age. It is also in agreement with previous studies showing a lack of ductal shunting found with hypoxia
(12), bacterial infusion (23-25), or graded increases in PAP (26) to induce pulmonary hypertension.

Because these results showed no change in any of the hemodynamic parameters in all conditions studied, we analyzed the potential for false-negative results introduced by possible type II errors in each group studied (27). With a sample size of six piglets in groups I through III, after pancuronium administration, up to a $35 \%$ change in most of the hemodynamic parameters would have been detected with 85 to $100 \%$ confidence.

\section{DISCUSSION}

Our results demonstrate that pancuronium administration under conditions of normoxia, hypoxia, or preexposure to hypoxia had no significant effects on measured hemodynamics in the anesthetized newborn piglet with normal lungs for up to 20 min after administration. We believe that, by controlling ventilation through adjustments in $\mathrm{V}_{\mathrm{T}}$ and ventilator rate, changes in $\mathrm{PaCO}_{2}$ and the increase in PAP typically associated with hypercarbia were prevented. An increase in PAP was demonstrated in preliminary studies (see Materials and Methods) when $V_{T}$ and $\mathrm{V}_{\mathrm{E}}$ were not adjusted after pancuronium, with cessation of spontaneous respirations. This supported our hypothesis that it is important to maintain ventilation after drug administration so as not to confuse effects due to hypoventilation after muscle paralysis with any direct hemodynamic effects of pancuronium.

Our failure to demonstrate any direct hemodynamic actions of pancuronium in the neonatal piglet are in agreement with Wolfson and Shaffer (28) and in partial agreement with Cameron et al. (13); both groups showed no change in baseline HR or 

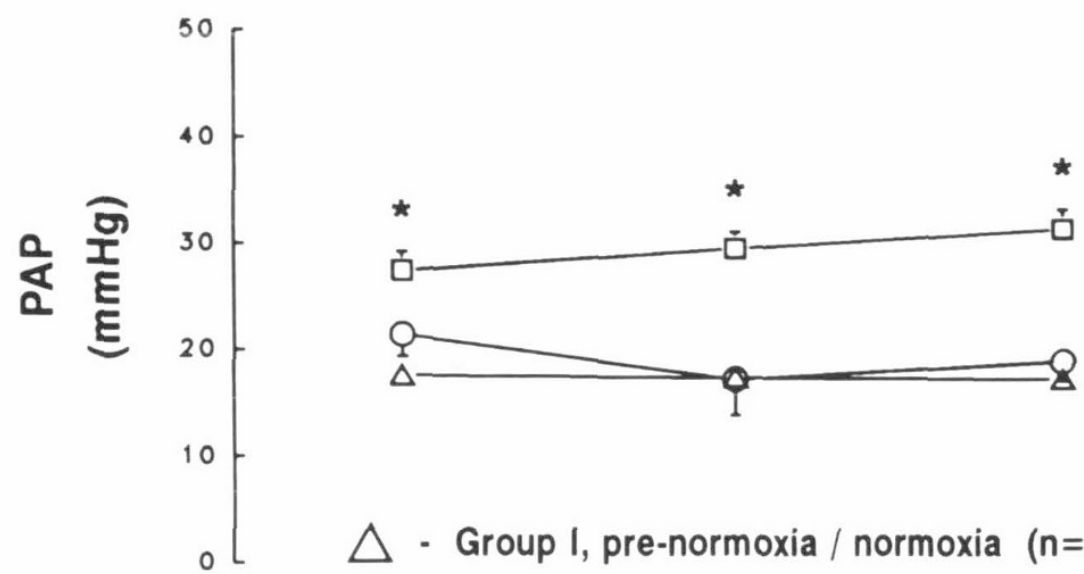

$\triangle$ - Group I, pre-normoxia / normoxia $(n=6)$

- Group II, pre-normoxia / hypoxia $(n=6)$

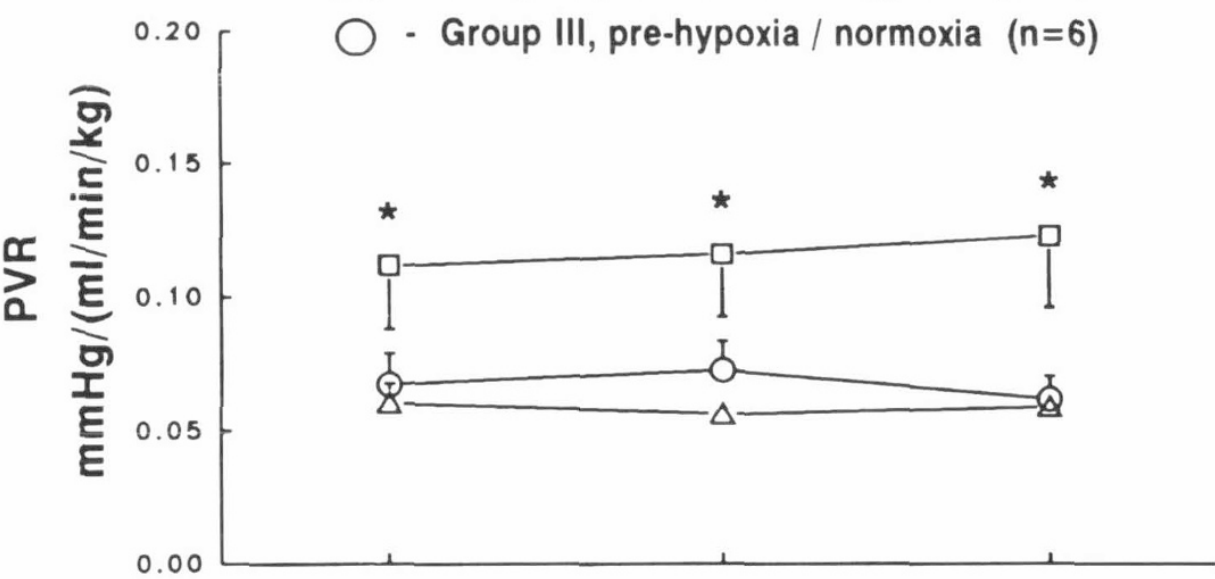

Baseline

Pan

At \& Neo

Fig. 5. PAP and PVR in group I vs II vs III. PAP or PVR in $\mathrm{kPa}=$ value $\times 0.1333$. Values are mean \pm SEM. *, group II is significantly different from groups I and III $(p<0.05)$.

MAP after pancuronium administration in anesthetized and nonanesthetized newborn lambs, respectively. However, although Cameron et al. showed no effect on CO or SVR as in the present study, they reported significant increases in PAP and PVR after administration of pancuronium during hypoxia and mechanical ventilation as compared with the same animals previously observed while spontaneously breathing during hypoxia (13). Their observed increases in PAP and PVR during hypoxia could not be duplicated in the nonhypoxic pancuronium-treated animal. The difference between their results and ours may have been due to their study design. $\mathrm{PaCO}_{2}$ levels during hypoxia were lower when the lambs were spontaneously breathing than when they were mechanically ventilated after pancuronium administration. We believe that, although these $\mathrm{PaCO}_{2}$ differences were not statistically significant, they were nevertheless of sufficient magnitude to account for differences in PAP and PVR between groups. Indeed, in our study, in which the ventilation of animals was controlled throughout hypoxia before and after pancuronium administration, no change in $\mathrm{PaCO}_{2}$ was allowed, and no changes in pulmonary hemodynamics resulted.

The effects of pancuronium in our study were observed during pentobarbital anesthesia. Although the pentobarbital may have attenuated any potential effects of pancuronium, despite this anesthesia, these piglets maintained the capacity to respond to vasoconstrictor stimuli such as hypoxemia or hypercapnia (as evidenced in preliminary experiments and in hypoxia-exposed animals) with increased PAP. This is in keeping with observations of Unger et al. (14), who showed that even large doses of pentobarbital did not blunt the pulmonary vasoconstrictor re- sponse to hypoxia in dogs. Furthermore, the lack of pancuronium effect on HR or MAP in our study was similar to results of previous studies using neonatal animals $(13,28)$, one of which used an unanesthetized preparation (13).

The rationale for hypothesizing that pancuronium may have had some immediate or delayed hemodynamic actions is that although the primary action of pancuronium is competitive inhibition of acetylcholine at the neuromuscular postjunctional membrane there are other reported direct effects. Pancuronium is believed to block muscarinic receptors (29), and a vagolytic effect is thought to be the mechanism responsible for increased HR and blood pressure after pancuronium administration documented in human studies (30). Increased norepinephrine release (31) and inhibition of norepinephrine reuptake at the sympathetic nerve terminal (32) after pancuronium has been demonstrated. Pancuronium has also been shown to cause the release of histamine, as well as to cause ganglionic blockade by competing for acetylcholine at the autonomic ganglia (33).

Despite the potential direct effects of pancuronium, other studies suggest that certain effects of pancuronium are indirect and occur as a consequence of muscular paralysis (34-37). In regard to this, our study is consistent with the hypothesis that many of the observed hemodynamic effects of pancuronium may be secondary to altered ventilation after muscle paralysis and associated changes in $\mathrm{PaCO}_{2}$.

In conclusion, pancuronium administration during normoxia, during hypoxia, and after preexposure to hypoxia does not alter the hemodynamic status of the newborn pig under conditions of controlled ventilation. These data suggest that the safe use of 


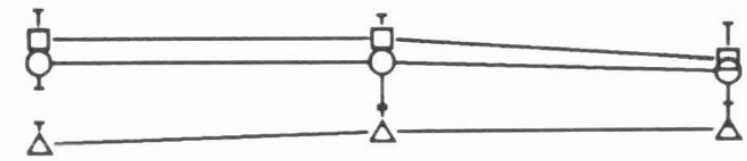

$\triangle$ - Group I, pre-normoxia / normoxia $(n=6)$

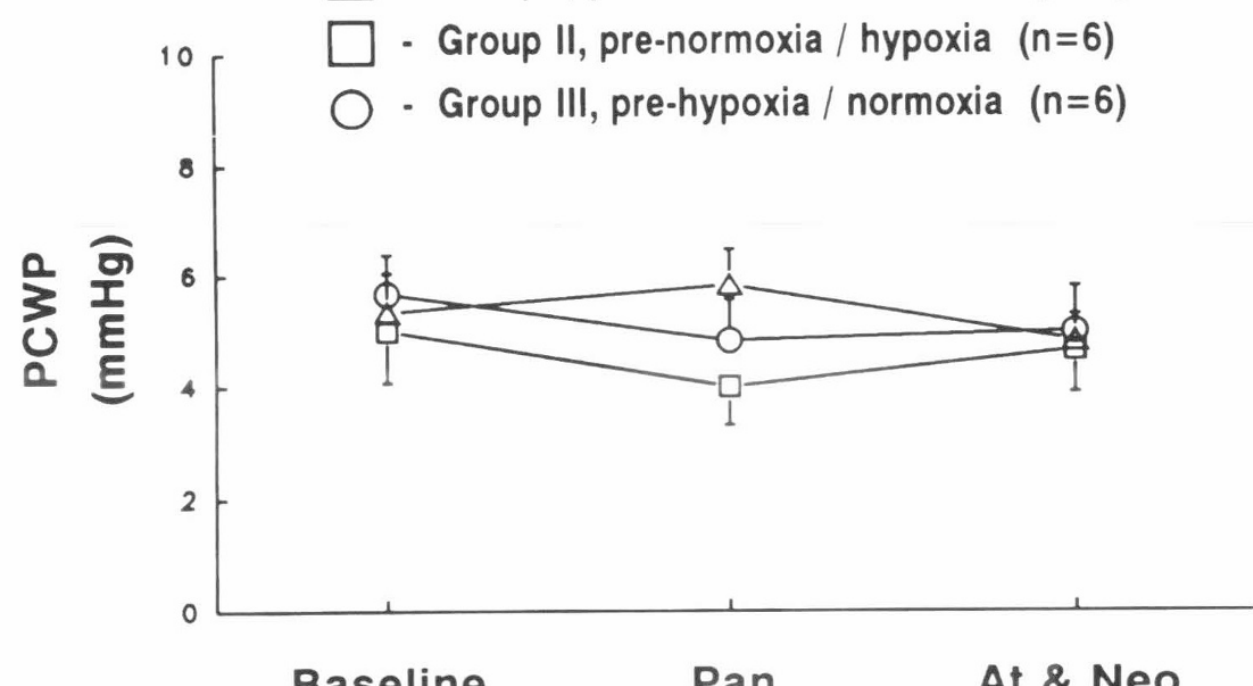

Baseline

Pan

At \& Neo

Fig. 6. CVP and PCWP in group I vs II vs III. CVP or PCWP in $\mathrm{kPa}=$ value $\times 0.1333$. Values are mean $\pm \mathrm{SEM}$.

pancuronium clinically requires careful bedside monitoring of respiratory parameters to keep $\mathrm{V}_{\mathrm{T}}$ and $\mathrm{V}_{\mathrm{E}}$ constant after spontaneous respirations are eliminated.

Acknowledgments. The authors thank Kenneth T. Nakamura, M.D., and Susan Pelke, R.N., for their review of this manuscript.

\section{REFERENCES}

1. Philips JB 1990 Treatment of PPHNS. In: Long WA (ed) Fetal and Neonatal Cardiology. WB Saunders, Philadelphia, pp 691-701

2. Costarino CTA. Polin RA 1987 Neuromuscular relaxants in the neonate. Clin Perinatol 14:965-989

3. Runkle B, Bancalari E 1984 Acute cardiopulmonary effects of pancuronium bromide in mechanically ventilated newborn infants. J Pediatr 104:614-617

4. Crone RK. Favorito J 1980 The effects of pancuronium bromide on infants with hyaline membrane disease. J Pediatr 97:991-993

5. Philips JB. Setzer ES. Drummond WH. Nelson RM. Eitzman DV 1979 Hypoxemia in ventilated neonates after pancuronium paralysis. Lancet 1:877

6. Bergin AM. Clarke TA. Matthews TG 1988 Problems with pancuronium in the neonatal intensive care unit. Ir Med J 81:39-40

7. Cabal LA. Siassi B. Artal R. Gonzalez F. Hodgman J, Plajstek C 1985 Cardiovascular and catecholamine changes after administration of pancuronium in distressed neonates. Pediatrics 75:284-287

8. McIntosh $\mathrm{N} 1985$ Hypotension associated with pancuronium use in the newborn. Lancet 2:279

9. Cohen NH 1980 Hemodynamic effects of pancuronium in critically ill children. Anesthesiology 53:S159

10. Miall-Allen VM, Whitelaw AGL 1987 Effect of pancuronium and pethidine on heart rate and blood pressure in ventilated infants. Arch Dis Child $62: 1179-1180$
11. Finer NN. Tomney PM 1981 Controlled evaluation of muscle relaxation in the ventilated neonate. Pediatrics 67:641-646

12. Dickstein PJ. Trindade O, Goldberg RN, Bancalari E 1984 The effect of calcium antagonists on hypoxic pulmonary hypertension in the piglet. Pediatr Res 18:1262-1265

13. Cameron CB, Gregory GA, Rudolph AM, Heymann MA 1986 Cardiovascular effects of d-tubocurarine and pancuronium in newborn lambs during normoxia and hypoxia. Pediatr Res 20:246-252

14. Unger M. Atkins M. Briscoe WA. King TKC 1977 Potentiation of pulmonary vasoconstriction response with repeated intermittent hypoxia. J Appl Physiol 43:662-667

15. Goldstein R. Brazy J 1991 Narcotic sedation stabilizes arterial blood pressure fluctuations in sick premature infants. J Perinatol 9:365-371

16. Greenough A 1984 Letter to editor. Pancuronium administration and immediate hypoventilation. [letter] J Pediatr 105:849

17. Greenough A. Pool J. Lagercrantz H 1988 Catecholamine and blood pressure levels in paralyzed preterm ventilated infants. Early Human Dev 16:219224

18. Baboolal R, Kirpalani H 1990 Measuring on-line compliance in ventilated infants using hot wire anemometry. Crit Care 18:1070-1072

19. Seear M. Wensley D. Werner H 1991 Comparison of three methods for measuring respiratory mechanics in ventilated children. Pediatr Pulmonol 10:291-295

20. Rudolph AM, Yuan S 1966 Response of the pulmonary vasculature to hypoxia and $\mathrm{H}^{+}$ion concentration changes. J Clin Invest 45:399-411

21. Haworth G, Hislop AA 1981 Adaptation of the pulmonary circulation to extrauterine life in the pig and its relevance to the human infant. Cardiovasc Res 15:108-119

22. Evans JR, Rowe HG, Downie HG, Rowsell HC 1963 Murmurs arising from ductus arteriosus in normal newborn swine. Circ Res 12:85-93

23. Runkle B, Goldberg RN, Streitfeld MM. Clark MR. Buron E. Setzer ES. Bancalari E 1984 Cardiovascular changes in group B streptococcal sepsis in 
the piglet: response to indomethacin and relationship to prostacyclin and thromboxane A2. Pediatr Res 18:874-878

24. Meadow WL, Meus PJ 1984 Hemodynamic consequences of tolazoline infusion in neonatal group B streptococcal bacteremia: an animal model. Pediatr Res 18:960-965

25. Meadow WL, Rudinsky BF, Strates E 1986 Effects of phenylephrine on systemic and pulmonary artery pressure during sepsis-induced pulmonary hypertension in piglets. Dev Pharmacol Ther 9:249-259

26. Belik J, Light B 1989 Effect of increased afterload on right ventricular function in newborn pigs. J Appl Physiol 66:863-869

27. Detsky AS, Sackett DL 1985 When was a "negative" clinical trial big enough? Arch Intern Med 145:709-712

28. Wolfson MR, Shaffer TH 1990 Differential effects of pancuronium bromide on cardiovascular function in the neonatal lamb. Pediatr Pulmonol 8:233239

29. Sexana PR, Bonta IL 1970 Mechanism of selective cardiac vagolytic action of pancuronium bromide. Specific blockade of cardiac muscarinic receptors. Eur J Pharmacol 11:332-341

30. Kelman GR, Kennedy BG 1971 Cardiovascular effects of pancuronium in man. Br J Anaesth 43:335-338
31. Domenech S, Garcia RC, Saisian JMR, Loyola AQ, Oraz JS 1976 Pancuronium bromide: an indirect sympathomimetic agent. Br J Anaesth 48:11431148

32. Salt PJ, Barnes PK, Conway CM 1980 Inhibition of neuronal uptake of noradrenaline in the isolated perfused rat heart by pancuronium and its homologues Org 6368 and NC 45. Br J Anaesth 52:313-317

33. Taylor $P 1990$ Agents acting at the neuromuscular junction and autonomic ganglia. In: Gilman AG, Goodman LS (eds) The Pharmacological Basis of Therapeutics, 8th Ed. Macmillan, New York, pp 166-186

34. Greenough A, Gamsu HR, Greenall F 1989 Investigation of the effects of paralysis by pancuronium on heart rate variability, blood pressure, and fluid balance. Acta Paediatr Scand 78:829-834

35. Bhutani VK, Abbasi S, Sivieri EM 1988 Continuous skeletal muscle paralysis: effect on neonatal pulmonary mechanics. Pediatrics 81:419-422

36. Rutledge ML, Hawkins EP, Langston C 1986 Skeletal muscle growth failure induced in premature newborn infants by prolonged pancuronium treatment. J Pediatr 109:883-886

37. Sinha SK, Levene MI 1986 Pancuronium bromide induced joint contractures in the newborn. Arch Dis Child 59:73-75

\section{Announcement}

\section{Annual Meetings}

The American Pediatric Society, The Society for Pediatric Research, and The Ambulatory Pediatric Association will hold their annual meetings May 3-6, 1993 at the Sheraton Washington Hotel, Washington, DC. For further information, contact: APS/SPR Association Headquarters, 141 Northwest Point Blvd., P.O. Box 675, Elk Grove Village, IL 60009-0675, (708) 427-0205, FAX (708) 427-1305 or Ambulatory Pediatric Association, 6728 Old McLean Village, McLean, VA 22101, (703) 556-9222, FAX (703) 556-8729. 